\begin{tabular}{|l|l|l||}
\hline \multicolumn{2}{|c|}{ PublisherInfo } \\
\hline \hline PublisherName & $:$ & BioMed Central \\
\hline \hline PublisherLocation & $:$ & London \\
\hline \hline PublisherImprintName & $:$ & BioMed Central \\
\hline \hline
\end{tabular}

\title{
Dendritic cell function
}

\begin{tabular}{|l|l|l||}
\hline \multicolumn{2}{|c|}{ ArticleInfo } \\
\hline \hline ArticleID & $:$ & 4194 \\
\hline \hline ArticleDOI & $:$ & $10.1186 /$ gb-spotlight-20010905-01 \\
\hline \hline ArticleCitationID & $:$ & spotlight-20010905-01 \\
\hline \hline ArticleSequenceNumber & $:$ & 265 \\
\hline \hline ArticleCategory & $:$ & Research news \\
\hline \hline ArticleFirstPage & $:$ & 1 \\
\hline \hline ArticleLastPage & $:$ & 2 \\
\hline \hline & & RegistrationDate : 2001-09-05 \\
ArticleHistory & $:$ & OnlineDate \\
\hline \hline ArticleCopyright & $:$ & BioMed Central Ltd2001 09-05 \\
\hline \hline ArticleGrants & $:$ & \\
\hline \hline ArticleContext & $:$ & 130592211 \\
\hline \hline
\end{tabular}




\section{Jonathan B Weitzman}

Email: jonathanweitzman@hotmail.com

Dendritic cells are antigen-presenting cells that play a critical role in linking the innate and the adaptive immune systems. In the September issue of Nature Immunology, Francesca Granucci and colleagues at the University of Milano-Bicocca, Italy, report the results of an oligonucleotide microarray screen to identify genes regulated in dendritic cells following activation by Gram-negative bacteria (Nature Immunology 2001, 2:882-888). They analysed the transcriptome of the dendritic cell-line D1 at several time points after activation with bacteria. Their analysis identified changes in a large number of genes, including genes implicated in inflammation, apoptosis, signal transduction and transcription. Also, Granucci et al. observed an induction of interleukin 2 (IL-2) mRNA at early time points (4-6 hours) and confirmed the importance of dendritic cell-derived IL-2 using bone marrow dendritic-cells from $I L-2-/-$ knockout mice. These results provide a molecular clue to explain the priming of naive $\mathrm{T}$ cells by dendritic cells during the immune response.

\section{References}

1. Dendritic cells and the control of immunity

2. Nature Immunology, [http://immunol.nature.com]

3. University of Milano-Bicocca, [http://www.unimib.it]

4. Dendritic cell genes, [http://www.btbs.unimib.it/DCgenes] 